\title{
The Immigration Issue, Line System \& Legislative Politics in Colonial Assam (1927-1939): A Historical Study
}

\author{
Bodhi SattwaKar \\ Assistant Professor,Department of History,A.L.Choudhury College, Algapur, Hailakandi
}

\begin{abstract}
The British Colonial policy of immigration and the introduction of Line System had a great significance in the political arena of colonial Assam. From a socio economic problem it became a major political issue in the Brahmaputra valley. It was rightly observed that nothing had split the province more deeply and widely than the immigration problem and policy of land settlement in colonial Assam. The British officials tried to tackle the immigration problem by administrative measures like Line System followed by Colonization Scheme but with little success. The change of ministries in colonial Assam after 1937 was linked up with immigration problem, which defied any solution due to divergent approaches of the political leaders. In this article, I tried to find outthe role of legislative members of colonial Assam in connection to immigration issue and itsconsequences in the political history of Assam.
\end{abstract}

Keywords:British Colonial policy, Line System, immigration, Colonization Scheme, Legislative Council and Legislative Assembly of Assam

The British Colonial authorities encouraged immigration in Assam purely on economic ground. The establishment of tea and other industries in Assam during nineteenth century followed by the extension of cultivation of wastelands necessitated to follow a liberal immigration policy by the Colonial rulers. Accordingly, a good number of immigrant labourers and cultivators were brought for the purpose from outside the Brahmaputra valley to fulfill the economic interest of colonial rulers. ${ }^{1}$

In the beginning, the Assamese middle class of the Brahmaputra valley welcomed the arrival of immigrants and settling down in the vast wastelands of Assam considering economic development of the province. However, the continuous inflow of immigrants in the province, bulk of which were Muslims, particularly from the Mymensingh district of Bengal changed their attitude at the turn of the century. They began to realize that unless the flow of immigrants was checked, their economic and cultural life would be in danger.

It should be mentioned here that the number of Muslim population in the Brahmaputra valley was 3,65,540 in 1911 which rose to 5,94,981 in 1921 and 9,53,299 in 1931. The large scale immigration led to a shift in the demographic balance in favour of the Muslims with abnormal rise in their proportion from 9 percent in 1921 to 19 percent in 1931 and 23 percent in $1941 .^{2}$ This alarming rise in the population adversely affected the rural economy of colonial Assam. Mass immigration and occupation of wastelands, grazing and forest reserves posed a serious problem. Not only by offering tempting prices the immigrants were able to purchase lands from the local inhabitants, but also forcible occupation of lands by the immigrants were also reported which seemed to threaten the survival of the indigenous inhabitants.

In the beginning, the public opinion in the rural areas was too feeble and unorganized to focus the magnitude of the problem in its proper perspective. Slowly the immigration issue was assuming a serious turn. To prevent the rural tension between the two communities the Colonial district officials in Nowgong devised an administrative measure known as LineSystem in 1916 and implemented it in 1920. By this system, the indiscriminate settlements by the immigrants in the Assamese inhabited areas were prohibited. It demarcated areas for both immigrant settlers and the indigenous people. ${ }^{3}$

The Assamese public opinion against the immigrant issue was voiced through the AsamiyaSamrakshiniSabha. It pleaded for a restricted influx of people in Assam and favoured their assimilation with local language and culture. In December, 1925 the Assam Association urged the Government to stop immigration. ${ }^{4}$ The Colonial rulers from the beginning took the stand that there were sufficient wastelands available in Assam for the settlement of outsiders.

It should be mentioned here that until 1937, the party politics did not play any role in Assam legislatures. It was only Congress SwarajistParty, which was able to send some of its members in the Assam

\footnotetext{
${ }^{1} \mathrm{H}$ Bareh, Encyclopedia of North East India Vol.IIAssam (Mittal Publications Delhi, 2001).

${ }^{2}$ A C Bhuyan, Political History of Assam Vol-II(Publication Board Assam, Guwahati, 2008).

${ }^{3}$ A Guha, Planters Raj to Swaraj: Freedom Struggle \& Electoral Politics in Assam, 1826-1947, (New Delhi, ICHR, 1947)

${ }^{4}$ A C Bhuyan, op.cit.
} 
Legislative Council. On the other hand Muslim members of the Councilbeing elected as 'independent' used to form pressure group to obtain political benefits. Unlike the Congress they offered full cooperation to the Colonial Government. Several attempts were being made by the Assamese members of the Legislative Council for favourable outcome on the issue of immigration and settlement of wastelands by the immigrants in Assam. However, they faced vigorous objection from their Muslim counterpart and Government members.

In 1924, RohiniKantaHatiBarua of the Swarajist Party attempted legislative interference into the problem of immigration, but it was not accepted. Again, in 1925, another attempt was made by HatiBarua who demanded that certain amount of preferences should be given to the indigenous Assamese for the settlement of all available wastelands in Assam. He was strongly supported by another Council member Tara Prasad Chaliha. However, the attempt failed on account of strong opposition from both European and Muslim Council members. ${ }^{5}$

The efforts of the Assamese legislators continued in the direction of controlling immigration and preservation of wastelands for indigenous people. On 23rd July, 1927 Mahadev Sharma moved a resolution in the Council with a demand to prevent or restrict the settlement of wastelands in the province. He also demanded for the appointment of a Committee to go through the whole matter as regards availability of wastelands, and to reserve adequate areas of wasteland for future expansion of the indigenous people. ${ }^{6} \mathrm{He}$ was supported by legislators like BishnuChoron Bora, KasinathSaikia, Brajendra Narayan Choudhury and others.

In opposing the resolution,MaulaviKeramat Ali of Jorhat said that there should not be any artificial restriction to natural migration. MaulaviMunwar Ali of Sylhet opposed the resolution and said that it would be committing suicide to stop settlement of land with immigrants as they had brought with them a harder and improved method of cultivation.A.W.Botham, who spoke for the Government was of opinion that the proposed restriction without prohibition of transfer of land by the Assamese would be useless. ${ }^{7}$

Finally, the motion of Mahadev Sharma was defeated by eighteen votes to twenty five. Both Assamese and Bengali Hindu members voted for the motion while Muslim and European members voted against it. Although the motion was rejected, the Government agreed to call an All party Conference to examine the issue. Actually, the colonial rulers had no intension to stop inflow of immigrants but to put effective administrative control on settlement areas to derive more revenue benefits.

Finally in a meeting of all party Committee under the Chairmanship of A.W.Botham held in September, 1928, the idea of ColonisationScheme was approved. The first Colonisation Schemewas started in Nowgong in 1928 followed by one each at Barpeta, and Mangoldai. Up to 1933, an area of 47,636 areas of land in Nowgongwas allotted among the immigrant families. ${ }^{8}$

The immigrants, however, did not like any restrictions, which put a barrier in their free choice of settlement areas. Meanwhile many immigrant families had acquired thousand bighas (land measuring unit) of land and they brought labourers either to work in it or for the purpose of subletting.

With the change of demographic pattern, the immigration issue which was basically a socio-economic in nature assumed a political character. The Muslim leaders of both Brahmaputra and Surma valley voiced opposition to the anti-immigration move as demanded by the indigenous Assamese people.On the other hand, the Assamese public opinion as voiced through the Council debates, the RyotSabhas, the Assamese SamrakshiniSabha and the Assamese press were vocal enough in opposing anti-Line propaganda. The North MangoldaiRyotSabha,and the Na-DuarRyotSabha strongly demanded for continuation of the Line System. ${ }^{9}$

The immigrants received wordy support both from Assamese and Bengali Muslim leaders as they hoped that influx of immigrants would numerically strengthen the base of Muslim communal politics in the province. On 16th March, 1936, Nuruddin Ahmed brought a resolution in the Council demanding abolition of Line System as he felt that it had stood in the way of absorbing the immigrants into the Assamese society. He was supported by Abdul MazidZioshshms, Abdul Khalique Choudhury and others. However, the resolution was lost by seven votes to twenty. All the seven supporters were Muslims and almost all the Hindu members of the Council voted against the motions. The Government side did not vote. ${ }^{10}$

Another attempt at abolition of the Line Systemwas made in 1937 by the Muslim legislators through a motion of Munwar Ali, a prominent Sylhet leader. In the meantime, a cabinet headed by Saadulla had come to power in Assam after the general election held in February, 1937 under the Provincial Autonomy sanctioned by the Government of India Act, 1935. Though in the election Congress emerged as the single largest party but

\footnotetext{
${ }^{5}$ M Kar, Muslims in Assam Politics, (Omsons Publications, Delhi, 1990)

${ }^{6} \mathrm{~S}$ Nag, Roots of Ethnic Conflict: Nationality Question in North East India, (Monahan Publications, New Delhi, 1990)

${ }^{7} \mathrm{M}$ Kar, op.cit.

${ }^{8}$ A Guha, op.cit.

${ }^{9}$ A C Bhuyan, op.cit.

${ }^{10}$ BimalJ Dev\&Dilip Kumar Lahiri, Assam Muslims: Politics \& Cohesion (Mittal Publications,1985)
} 
Saadulla ,the leader of the Muslim Group of the Brahmaputra valley was able to form a coalition government with the help of the Europeans and tribal members. He took the office of the Premier on 1st April, $1937 .{ }^{11}$

Munwar Ali in demanding the abolition of Line System said that the Line System was a line which was arbitrarily drawn to restrict the Indians to move from one place to another of his own country. It was against the idea of building up of Indian nationhood. Abdul Motin Choudhury, Maulavi Mubarak Ali, Khan Sahib MudabbirHussain Choudhury and others, supported him. ${ }^{12}$ They supported the cause of immigration on the strength of section 298 of the Government of India Act, 1935that was a guarantee against discrimination on grounds of race, religion and place of birth.

Rohini Kumar Choudhury, who was the Minister of Revenue in the Saadullacabinet offered to appoint a Committee to enquire into the question. Accordingly, a Committee was appointed under the Chairmanship of F.W.Hockenhull, The Committee submitted its report in February, 1938. Some members of the Committee preferred for the abolition of Line System and some favour to retain in its present form. The Committee then worked out on conflicting views and submitted their recommendations as a united Committee to Saadulla. ${ }^{13}$

The Committee considered it undesirable to relax all restrictions on the immigrants in the matter where the immigrants should or should not take up lands. It also recommended for abolition of artificial barriers imposed in the immigrants acquiring patta lands. However, the Committee was in favour of reserving large areas of the province for the expansion of indigenous cultivation. It also recommended for the extension of the 'Colonization Schemes', where it existed and to start new one if necessary. According to the Committee, the haphazard method of settlement by squatting must come to an end.The Committee,however, expressed the view that without firmness of administration, avoidance of unnecessary interference and an adequate and competent staff to enforce the executive orders, the recommendations' would have no value. ${ }^{14}$

Hardly six months had passed since the publication of the report when in September 1938; the Saadulla coalition cabinet was broken by the first Congress coalition headed by GopinathBordoloi. Bordoloi had nearly fifteen months of time to look into the matter, but took no action. Only about a week before his resignation, his cabinet adopted a resolution on 4th November, 1939 accepting the report in general term. The resignation of Bordoloi left the field open for Saadulla who formed second coalition on 22nd February, 1940. Till 1946, he was Premier six times and followed a policy of settlement which was severely criticized both by Hindus and Congress party. ${ }^{15}$

The Congress under GopinathBordoloi when came to power after the general elections of 1946, decided to evict immigrants from the professional grazing grounds. This prompted the Provincial Muslim League Committee under Bhasani to agitate against the eviction policy of the Congress.In April 1946, The All India Muslim League Legislator's Convention was held at Delhi, which demanded inclusion of Assam in Pakistan. ${ }^{16}$

\section{Conclusion}

Therefore, the immigrants issue and the policy of land settlement, which was originally a socioeconomic issue, became politicised on communal lines resulting into the demand of Assam's inclusion in the map of Pakistan.

\section{References:}

[1]. H Bareh, Encyclopedia Of North East India Vol.Iiassam (Mittal Publications Delhi, 2001).

[2]. A C Bhuyan, Political History Of Assam Vol-II(Publication Board Assam, Guwahati, 2008).

[3]. A Guha, Planters Raj To Swaraj: Freedom Struggle \& Electoral Politics In Assam, 1826-1947, (New Delhi, ICHR, 1947)

[4]. M Kar, Muslims In Assam Politics, (Omsons Publications, Delhi, 1990).

[5]. S Nag, Roots Of Ethnic Conflict: Nationality Question In North East India, (Monahar Publications, New Delhi, 1990)

[6]. Bimal,Jdev\&Dilip Kumarlahiri,Assam Muslims: Politics \& Cohesion (Mittal Publications, 1985)

[7]. Nripen Dhar, Impact Of Immigration In Assam, 1871-1951 (Worldview Publication, 2005)

[8]. Report Of The Line System Committee (1938)

\footnotetext{
${ }^{11} \mathrm{M}$ Kar, op.cit.

${ }^{12}$ Nripen Dhar, Impact of Immigration in Assam, 1871-1951 (Worldview Publication, 2005)

${ }^{13}$ Report of the Line System Committee (1938)

${ }^{14}$ Ibid.

${ }^{15}$ Bimal,JDev\&Dilip Kumar Lahiri, op.cit.

${ }^{16}$ Nripen Dhar, op.cit
} 